\title{
THE SIGNIFICANCE OF ORGANISATIONAL CULTURE IN THE DEVELOPMENT OF HUMAN CAPITAL
}

\author{
Maciej GITLING \\ University of Rzeszów, Institute of Sociology, Department of the Sociology of Organisations and \\ Management; maciej.gitling@gazeta.pl, ORCID: 0000-0003-1958-8564
}

\begin{abstract}
Purpose: The chief purpose of this article was to draw attention to the importance of organisational culture as a crucial factor in human capital management. In order to achieve this goal, reports of research on the competitiveness of small and medium-sized enterprises in Poland were read, with respect to investments in human capital development.
\end{abstract}

Design/methodology/approach: The literatures on management sciences, sociology of organisations and economics were also reviewed, on the basis of which a theoretical description of selected issues was made. The issues included factors shaping organisational culture and its influence on human capital development. The analysis of the literature showed that organisational culture may perform many functions in the integration and development of human resources, including the development of human capital. Organisational culture is a carrier of specific norms and values preferred by both managers and employees.

Findings: Nowadays, human capital generating new quality of knowledge is recognised as a strategic factor of enterprises and the basis for their prosperity. It therefore becomes an issue of core importance for managers to effectively manage human capital in such a way that it would encourage creativity, the ability to acquire knowledge and to shape working competences. One should remember that enterprises differ in respect of ability to define, communicate and manage organisational culture. Owing to the literature review, it was found that through the study of organisational culture it is possible to create value and a competitive position of enterprises based on human capital development.

Originality/value: The subject of the article may be useful for both practitioners of economic life, as well as theoreticians studying organisational culture and human capital.

Keywords: organisational culture, human capital, competitiveness.

\section{Introduction}

Research into the impact of organisational culture elements on the functioning of an organisation, on the behaviour of its members and on the effectiveness of achieving intended goals is a difficult task, due to the lack of structured procedures which would have clearly allowed 'the forms of culture' in an organisation to be identified. 
It should be noted that organisational culture is shaped by a series of both external and internal factors. Organisational culture sometimes varies across individual continents of the modern world. Nowadays, the process of globalisation favours the cultural diversity of both labour market and enterprises themselves. This leads to the tendency of establishing international companies on a larger and smaller scale and intercultural management. H. Steinmann and G. Schereyögg indicate that the term 'enterprise culture' shall mean an enterprise as a kind of cultural system in which original and very own patterns and orientations are developed, which effectively leave a mark on the behaviour of employees and the functioning of an enterprise (Steinmann, and Schereyögg, 1995, p. 417).

The phenomenon of organisational culture is a complex issue that involves the entire environment of entities forming a company. Culture should be viewed as a stimulus or a slowdown of the development of every enterprise.

On the other hand, human capital management in an organisation shall connote the models of shaping human resources, the purpose of which is to identify the dimensions of culture that are important for raising the value of human capital and processes and solutions in the field of management, which contribute to developing the culture in the desired way.

H. Król points out that 'the creation and development of human capital is a crucial element of the concept of human capital management in the process of implementing the personal function of modern and future organisations. This is only a process of shaping a new model of managing people, replacing typical personnel administration or newer human resource management' (Król, 2007, p. 21).

Treating human capital as a company's most valuable capital is based on the recognition that it creates economic values for the entrepreneur. Investing in human capital is a critical factor in both the competitiveness of enterprises and economic growth.

A. Stańda notes that 'from a cognitive, scientific, as well as an application point of view, the contextual significance of organisational culture in the processes of building competitive advantage is today widely accepted' (Stańda, 2012, p. 45). The culture gives employees indications on how to behave, what to do and what to prioritise. It bridges the gaps between what is described in formal procedures and instructions and what is actually going on in an enterprise.

Reports of research on the competitiveness of small and medium-sized enterprises in Poland indicate that in the last decade, enterprises were investing in the development of human capital to a different extent. In this regard, the gap between theory and practice can be quite significant (see: Szaban, 2007, p. 159; Lewicka, 2010; The Operational Programme Knowledge Education Development 2014-2020).

It is also important that the European Commission put into effect decision no. K(2007) 4547 to implement the Human Capital Programme, which was one of the programmes for the implementation of the National Strategic Reference Framework 2007-2013 and covered the entire intervention of the European Social Fund (ESF) in Poland. The programme was an 
answer to challenges posed by the revised Lisbon Strategy on Member States of the European Union, including Poland. These challenges incorporated: making Europe a more attractive place for investments and working, developing knowledge and innovation, as well as creating a larger number of permanent work places. According to the assumptions of the Lisbon Strategy and goals of the cohesion policy, the development of human and social capital contributes to more efficient use of work resources and fosters the growth of an economy's competitiveness (Human Capital. National Cohesion Strategy, 2007).

On 17 December 2014, the European Commission approved the Operational Programme Knowledge Education Development, which addressed the need for reforms in the areas of employment, social inclusion, education, higher education, healthcare and good governance.

The funds from this programme make a significant contribution to raising human capital in economic organisations, local government institutions, as well as in higher education.

\section{Factors Shaping Organisational Culture}

There is a variety of definitions of organisational culture. According to K. Cameron and R. Quinn, 'organisational culture is a field in which conceptual work and studies were guidelines for organisations seeking ways of improving their effectiveness' (Cameron and Quinn, 2015, p. 27). Ł. Sułkowski rightly notes that 'the multitude of definitions of organisational culture itself, as well as the description of its components, typology and relationships with an environment and other areas of an organisation, is the obvious consequence of the lack of one paradigm and even an agreement of research on one way of ordering approaches to organisational culture' (Sułkowski, 2008, p. 12).

The culture is reflected in the behaviours and relationships of individuals and groups of employees and pervades all areas of activity of every organisation. Organisational culture is a process which is constantly evolving; however, it should be emphasised that all organisations possess a characteristic culture, which is a set of recognised values and commonly shared beliefs about how people should behave at work.

W. Nickels states that the general culture (tradition) of an enterprise, which is defined as values recognised universally throughout an organisation, ensuring cohesiveness and cooperation in achieving common goals, is one of the key success factors for organisations. The author writes that corporate culture is created by leaders who evoke an atmosphere of respect for values which have a positive or negative impact on relations and various environments within an institution. The best institutions possess a culture placing an emphasis on serving others, especially customers. Good leaders produce a culture which stimulates the willingness to cooperate and the involvement of employees in creating products and services (Nickels, 1995, pp. 375-376). 
J. Stoner and Ch. Wankel point out that organisational culture encompasses common customs, concepts, norms, values, attitudes and beliefs which are followed by employees and managers of that particular organisation (Stoner and Wankel, 1994, p. 327).

Similarly, M. Armstrong claims that corporate culture is created by shared beliefs, attitudes and values which, although not always articulated, affect the frame of actions and mutual interpersonal contracts (Armstrong, 1996, p. 86).

J. Penc, with reference to M. Armstrong's works, highlights that the development of culture concerns (as cited in Penc, 2005, p. 268):

- 'cultural changes, the development of attitudes, beliefs and values which would be consistent with the mission, strategy, environment and technology of an enterprise. This means achieving significant changes in organisational climate, management style and behaviours which would positively support completing an enterprise's objectives;

- cultural strengthening, which is aimed at preserving and strengthening what is good and functional in existing culture;

- managing changes, which is related to enabling a culture to effectively adapt to changes and obtaining approval for changes in enterprises, systems, procedures and methods of work;

- stimulating commitment, which is associated with the identification of employees with the enterprise's mission, strategy and values'.

H. Januszek and J. Sikora state that it is characteristic of organisational culture that it (Januszek and Sikora, 1998, pp. 53-54):

- is shaped by human beliefs, behaviours and ways of thinking, thus affecting their demeanour;

- applies to the entire organisation, but only when the team accepts and practices desired systems of values and norms;

- determines and controls employee behaviour. When they deviate from the accepted standards, various appropriate measures are taken, from official negation to an employee's exclusion from an organisation;

- is incorporated not only in applicable procedures, but also in the views and ways of thinking of employees;

- develops a stronger or weaker dependence on its external cultural environment and political, social and economic or ideological factors.

Citing the research of other authors, S. Robbins draws attention to seven essential characteristics related to organisational culture. These are (Robbins, 2001, p. 244):

- Innovation and risk taking, the extent to which employees are encouraged to take risks and launch innovations. 
- Attention to detail, the extent to which employees are expected to be accurate and have attention to detail.

- Results orientation, the extent to which the attention of managers is focused on the results and effects instead of the methods and processes used to achieve these outcomes.

- Human orientation, the extent to which the decisions of the managers take into consideration the effects of the obtained results on organisation members.

- Team orientation, the extent to which work is organised around teams rather than individuals.

- Assertiveness, the extent to which employees display aggressive behaviour and competition among themselves rather than satisfaction with the achieved position in a company.

- Stability, the extent to which an organisation wishes to preserve the status quo rather than strive for its own development.

\section{Functions of Culture}

The functions carried out by organisational culture are closely associated with the policy of an organisation and human resource management. Large companies provide employees with appropriate training, during which new workers have the opportunity to familiarise themselves with the organisation's norms, values and artefacts in order to adapt them to new working conditions and incorporate the values that an organisation considers the most important as soon as possible.

According to S. Sudol, organisational culture that is considered as beneficial should be preserved and fostered through (Sudoł, 2005, p. 323):

- 'including it in the network of a company, which can also be expressed in a company's postulate of compliance with its organisational culture;

- employing people with traits matching the existing organisational culture and dismissing those who do not perceive it;

- educating and improving the staff and influencing their attitude;

- rewarding and promoting employees who behave in accordance with the existing culture;

- leading by example, constituting a role model for personnel;

- promoting cooperation with external partners sharing a similar organisational culture;

- implementing culture through slogans and celebrations'. 
Organisational culture may serve many functions. E.G. Schein divided them into two groups (as cited in: Kubik, 2008, p. 319).

"In terms of external adjustment, culture:

- allows members of an organisation to understand its missions and strategies and to identify its primary goal;

- facilitates integration between the members, as it offers a consensus related to the goals that can be deduced from the missions and strategies of an organisation;

- facilitates integration around measures adopted to achieve an organisation's goals and enhance the involvement of employees. Culture offers an agreement on how and with what resources one can and should act;

- provides the members with consistent measurement methods and criteria for accessing effects, and thus individuals and groups may agree on whether the goals have been achieved and, if so, to what extent;

- allows one to improve measures and redefine goals if a change is needed;

- enables the members to develop a strategy of change, as well as a direction and the ways to improve an organisation.

In terms of internal integration, culture:

- offers a common language and conceptual framework. Integration is not possible if the members are unable to communicate with one another;

- defines group boundaries, as well as acceptance and rejection criteria. The division of individuals and groups in an organisation into "we" and "they" is extremely important for its efficient functioning;

- sets power rules and status criteria. Organisational culture allows for the avoidance of conflicts over power, many negative emotions and aggressive behaviours;

- helps meet an organisation's security and affirmation needs;

- incorporates criteria for reward and punishment. Thanks to this, groups gain a common basis for assessing behaviours, attitudes, decisions and motivations, and each member acquires knowledge of what is considered by an organisation and a team as good or bad. Culture also determines a common system of reinforcements and integrates people's perception of what is a reward or punishment".

J. Penc argues that every social culture in an organisation has four basic functions (Penc, 2010, p. 80):

- integrative, which consists in maintaining an organisation in its entirety. It therefore encompasses what is common and brings people together, ignoring what is individual and differentiating;

- perceptual, which refers to perceiving the organisational environment and attaching importance to social and organisational life. Thanks to this function, the members of an organisation know how to view the organisation and its environment. Culture 
provides them with all necessary information on the degree of self-control, perception of a certain order and way of understanding the rationality;

- adaptive, which consists in providing already-prepared procedures for many situations. It contributes to reducing the uncertainty of situations related to the functioning in an evolving environment and to improving the ability to deal with the problems of external adaptation and internal integration;

- motivational, in which a well-formed culture increases the degree of employee involvement in effective operation of an organisation. Committed employees accept the company's goals as their own and pursue them constantly. Their behaviour is governed by a sense of what is good or bad, as well as by moral responsibility. Organisational culture has a direct impact on the shaping of work culture.

M. Kostera and S. Kownacki, citing E. Schein, state that internal integration is of great significance, because it influences the implementation of the strategy adopted by a given organisation. In terms of internal integration, culture serves the following functions (Kostera and Kownacki, 1995, pp. 302-303):

- it offers a common language and conceptual framework. A common language is the binder conditioning the proper communication of all members of an organisation. Without it, they are unable to communicate with each other. It is often the language that divides employees into 'bottom' and 'top', which leads to creating unnecessary language barriers;

- it defines group boundaries, as well as acceptance and rejection criteria. Employees are divided into those who are members of organisational culture and those who are not, whereby the division into 'we' and 'they' is, at the same time, very important for the functioning of an organisation. These boundaries can only be shaped rationally, increasing integration, thanks to using organisational culture as a management tool;

- it sets power rules and status criteria, because organisational culture helps to avoid conflicts over power, as well as many negative emotions and aggressive behaviours. It defines how authority is achievable, how it can be preserved and used. It offers a common system of values related to organisational influence and informs about what is allowed and what is prohibited, as well as whether, when and how managers and their decisions and suggestions can be criticised;

- knowledge and perception of culture influence the organisational needs of security and affiliations;

- it includes criteria for reward and punishment, in which groups gain a common basis for assessing behaviour, decisions, attitudes and motivations, and each member acquires knowledge of what is considered by an organisation and a team as good or bad. Culture also determines a common system of reinforcements, integrating people's perception of what is a reward or punishment; 
- it offers religions and ideologies. In every workplace, there are sudden and incomprehensible occurrences. These must gain meaning and explanation in such a way that employees do not have a fatalistic attitude towards the world and an organisation. Organisational culture offers such an interpretation, helping reduce stress and anxiety arising from uncertainty caused by, for example, introducing changes and innovations or the restructuring of a company.

Organisational culture provides a shared vision of the organisation world, which is based on ethical premises. L. Zbiegień-Maciąg points out that culture in an enterprise 'shapes people's behaviour and expectations. Culture influences people, although they are not always aware of its existence. The dream and, at the same time, the goal of many currently operating companies is to build a strong and effective culture' (Zbiegień-Maciąg, 2013, p. 18).

Culture becomes a burden when common values are not consistent with those leading to an increase in an organisation's effectiveness. Such situations are most likely to occur when the environment of an organisation is dynamic.

It should be stressed that organisational culture is strongly and traditionally associated with the national culture of a given country. Organisational culture existing in European countries is different from those developed in Japan, the US and Asian countries.

\section{The Impact of Organisational Culture on the Development of Human Capital}

Similar to organisational culture, the concept of human capital is also extremely difficult to define unambiguously. In general, it may be assumed that human capital is capital existing in people, and people are not owned by a company, but their potential remains at the disposal of an employer in virtue of specific legal relationships (as cited in: Moczydłowska and Kowalewski, 2014, p. 32).

H. Król claims that 'human capital in an organisation encompasses a set of specific features and properties incorporated in employees (knowledge, skills, abilities, health, motivation), which have a certain value and are sources of future income for both an employee, the owner of human capital, and for an organisation benefiting from the capital under particular conditions' (Król, 2007, p. 97). J. Oczki indicates that enterprises which will be able to develop an organisational culture encouraging the accumulation of human capital may be given the chance to gain an advantage (Oczki, 2009, p. 228).

In times of increasing economic competition, more attention is drawn to the competence potential of employees. Human capital is increasingly perceived as a source of the competitive advantage of enterprises. Many practitioners and theorists agree on the role of knowledge and skills as sources of competitive advantage. The significance of human capital is also considered 
depending on what a given organisation sees as most important. B. Kożuch states that achieving market success by highly innovative companies, including intelligent organisations, is the justification for orienting enterprises towards human capital. Emphasis upon human capital helps the company achieve success through developing an effective work style (Kożuch, 2009, p. 77).

In the age of knowledge-based economies, investments in human capital are a fundamental element of human capital theory. They may be seen as all activities that affect an economy's value, development and achieved financial results through increasing resources existing within members of an organisation. Employees' competitive potential and organisational knowledge becomes a way of achieving and maintaining a competitive advantage (Moczydłowska and Kowalewski, 2014, pp. 30-31). Competitiveness at the company level means developing a specific pattern of actions and behaviours within the competitiveness strategy. Shaping the company's competitiveness is a dynamic process with result and factor elements. The competitive potential of companies, i.e. the possibilities and actions in the sphere of obtaining human resources and transforming them into key competences and abilities, is the source of their competitiveness. The increase in the role and significance of human capital, expressed in employees' competences and the need for its unique shaping in compliance with business requirements and a competitive strategy, gives priority to an enterprise's personal function (Maniak, 2009, p. 45). The advantage over competitiveness is increasingly less dependent on investment in physical assets and access to capital in favour of the importance of intangible knowledge, skills and relationships developed by employees. This required the creation of tools describing intangible assets. Because of the absence of such tools, companies encountered difficulties in managing something that they were not able to describe and measure (as cited in: Król, 2007, p. 106).

Human resource development may affect employees in order that they behave in accordance with the cultural standards of a given company. T. Peters and R. Waterman argue that enterprises may achieve excellence if they produce a culture which (as cited in: Fryczyńska, 2009, pp. 371-372):

- strengthens the autonomy of employees,

- promotes internal entrepreneurship and encourages it,

- strengthens the management's commitment to business and decision-making,

- focuses on the most important competences,

- is oriented towards providing customers with the desired value.

The model of human capital assumes the loyalty of employees, as well as integration and investment in knowledge (employee development). A special role falls upon managers, who should bear in mind that an employee should be treated as a unique resource, and investments in human resources are unlimitedly profitable. 
Enterprises of high culture see people as the most valuable resource. Accordingly, the forms of employee cooperation are included in management system, and thus suggestions are listened to and participation in decision-making and introducing innovations are facilitated.

Enterprises should therefore ensure that they develop such an organisational culture which aims at supporting and implementing the process of improving employees' qualifications and knowledge. M. Grzebyk states that 'employee development should be a core value for an organisation, an investment which may bring considerable benefits for both the organisation itself and its employees. It is a long-term process that fosters broadening employee's horizons and skills, developing individual qualities such as innovation and entrepreneurship, as well as satisfying the need for self-fulfilment' (Grzebyk, 2014, p. 118).

\section{Summary}

The work environment in a majority of enterprises is currently a place of mutual interaction between people from different cultures. Such a state of affairs gives rise to the existence of a number of different systems of values, work styles and attitudes towards work, ways of perceiving reality, preferences and beliefs. Managers are therefore bound by the obligation of taking into account the cultural context of management (Moczydłowska, Korombel and Bitkowska, 2017, pp. 84-85).

Organisational culture may create appropriate incentives to work, as well as stifle creativity and innovative ideas. Thanks to the study of organisational culture, there is a good chance of detecting errors in the process of human capital management.

One should remember that all enterprises possess their own specific culture, which may be modified in order to enhance their effectiveness. Nevertheless, K. Serafin notes that 'evolution in the cultural sphere proceeds much slower and more dispersed than strictly targeted changes in the structure of an organisation' (Serafin, 2015, p. 96). K. and P. Pilipczuk state that 'there are no bad and good organisational cultures, because every culture has its own advantages depending on the stage of the company's development, the market in which it operates and the type of industry. Therefore, it is important to consciously decide where we strive to be as an organisation, as well as what culture and on the basis of which values we want to build (K. \& P. Pilipczuk, 2018, p. 430).

C. Sikorski emphasises that 'the more common patterns of thinking and behaving and the people who accept these common patterns are, the stronger the culture of this organisation is' (Sikorski, 2008, p. 41). The model of human capital helps build organisational cultures based on loyalty, integration, cooperation and partnership. The sense of belonging to a company is ensured by organisational culture based on employee development, teamwork, cooperation, openness and friendship (Nohria, Groysberg and Lee, 2008, p. 82). 
E.G. Flamholtz and Y. Randle state that 'organisational culture exists even though it cannot be seen, touched, tasted and heard. It pervades all aspects of an organisation's life and has a profound impact on its success and failure. Properly managed culture can become a real economic asset. On the other hand, inefficiently managed or neglected culture can become a real burden and even lead to the bankruptcy of an enterprise' (Flamholtz and Randle, 2018, pp. 13-14). Flamholtz argues that culture should be treated as an asset or form of human capital of an organisation, even in the accounting sense.

Managers should therefore ensure that organisational culture is incorporated in every area of an organisation, and human capital is to be regarded as a strategic resource in which investment is required. It is thus important to implement the desired profile of organisational culture based on boosting and developing human capital.

In many enterprises, there is no integrated approach to human capital management, which would take into consideration the peculiarity of the enterprise and the uniqueness of employees' competences. Managerial staff should therefore consider: a thorough examination of the company's situation and its needs (the analysis should take into account the enterprise's strategy, its structure and organisational culture); creation of a properly selected incentive system for all positions in enterprises, which is consistent with the company's organisational culture and is related to many areas of human capital management, including assessment, remuneration and development; creation of development programmes for particular groups of positions; establishment of a training budget dedicated to specific departments; implementation of mentoring and coaching programmes, as well as succession plans, in order to reduce the outflow of unique knowledge from an organisation due to high fluctuation among some groups of employees; adoption of measures for better integration of employees around a common vision and the company's values.

D. Lewicka points out that the objective of strategic human capital management is to adopt a course of action in an unstable environment in such a way that it would be possible to turn an organisation's needs into a coherent and practical policy, as well as programmes and procedures coherent with the business strategy, in order to gain a competitive advantage. An organisation's mission and objectives related to human capital, as well as tools supporting the best usage of its resources and achieving goals, are based on the People Strategy (Lewicka, 2010, p. 27). 


\section{References}

1. Amstrong, M. (1996). Zarządzanie zasobami ludzkimi. Strategia i działanie. Kraków: Wydawnictwo Profesjonalnej Szkoły Biznesu.

2. Cameron, K.S., Quinn R.E. (2015). Kultura organizacyjna - diagnoza i zmiana. Model wartości konkurencyjnych. Warszawa: Wolters Kluwer.

3. Flamholtz, E.G., Randle, Y. (2018). Kultura firmy. Nowy kluczowy zasób strategiczny, którym jak najszybciej musisz zacząć zarządzać. Warszawa: ICAN Instytut.

4. Fryczyńska, M. (2009). Kulturowe uwarunkowania rozwoju zawodowego pracowników przedsiębiorstw. In: M. Juchnowicz (eds.), Kulturowe uwarunkowania zarzadzania kapitałem ludzkim. Kraków: Oficyna a Wolters Kluwer business.

5. Grzebyk, M. (2014). Rozwój i doskonalenie kapitału ludzkiego w organizacji. In: M. Grzebyk, A. Pierścieniak, P. Filip, Gospodarowanie kapitałem ludzkim w organizacji. $W$ kierunku poprawy efektywności pracy. Rzeszów: Wydawnictwo Uniwersytetu Rzeszowskiego.

6. Januszek, H., Sikora, J. (1998). Socjologia pracy. Poznań: Wydawnictwo Akademii Ekonomicznej.

7. Kostra, M., Kownacki, S. (1995). Kierowanie zachowaniami organizacyjnymi. In: A.K. Koźmiński, W. Piotrowski (eds.), Zarzadzanie. Teoria i praktyka. Warszawa: PWN.

8. Kożuch, B. (2009). Nauka o organizacji. Warszawa: CeDeWu.

9. Król, H. (2007). Kapitał ludzki organizacji. In: H. Król, A. Ludwiczyński (eds.), Zarządzanie zasobami ludzkimi. Tworzenie kapitalu ludzkiego organizacji. Warszawa: PWN.

10. Król, H. (2007). Wprowadzenie. In: Król H. (eds.), Zarządzanie kapitałem ludzkim a konkurencyjność małych i średnich przedsiębiorstw. Warszawa: Wydawnictwa Akademickie i Profesjonalne.

11. Kubik, K. (2008). Zarządzanie kulturą organizacji. In: J. Kardas, M. Wójcik-Augustyniak (eds.), Zarzadzanie w przedsiębiorstwie. Warszawa: Difin.

12. Lewicka, D. (2010). Zarzadzanie kapitałem ludzkim w polskich przedsiębiorstwach. Warszawa: PWN.

13. Maniak, G. (2009). Rosnąca presja konkurencji na rynku pracy - nowe wyzwania dla zarządzania zasobami ludzkimi. In: E. Skrzypek, A. Sokół (eds.), Zarządzanie kapitałem ludzki w gospodarce opartej na wiedzy. Warszawa: Instytut Wiedzy i Innowacji.

14. Moczydłowska, J., Kowalewski, K. (2014). Nowe koncepcje zarządzania ludźmi. Warszawa: Difin.

15. Moczydłowska, M., Korombel, A., Bitkowska, A. (2017). Relacje jako kapitał organizacji. Warszawa: Difin. 
16. Nickels, W.G. (1995). Zrozumieć biznes. Warszawa: Wydawnictwo Bellona i TNOiK.

17. Nohria, N., Groysberg, B., Lee, L. (2008). Employee Motivation. A Powerful New Model. Harvard Business Review, lipiec-sierpień.

18. Oczki, J. (2009). Możliwości wykorzystania narzędzi ZZL do kształtowania optymalnej kultury organizacyjnej w zmieniającym się otoczeniu przedsiębiorstw w Polsce. In: M. Juchnowicz (eds.), Kulturowe uwarunkowania zarządzania kapitałem ludzkim. Kraków: Oficyna a Wolters Kluwer business.

19. Penc, J. (2005). Role i umiejętności menedżerskie, sekrety sukcesu i kariery. Warszawa: Difin.

20. Penc, J. (2010). Kultura $i$ etyka w organizacji. Aspekty pragmatyczne i strategiczne. Szczytno: WSPol.

21. Pilipczuk, K., Pilipczuk, P. (2018). Budowanie wartości organizacji, czyli systemowe podejście do trustu. In: K. Popieluch (eds.), HR Business Partner. Rola, filary, perspektywy. Warszawa: PWN.

22. Program Operacyjny kapitat ludzki (Po KL) 2007-2013. Warszawa: Europejski Fundusz Spójności.

23. Program Operacyjny Wiedza Edukacja Rozwój 2014-2020. Warszawa: Wyd. Ministerstwo Infrastruktury i Rozwoju.

24. Robbins, S.P. (2001). Zasady zachowania w organizacji. Poznań: Wydawnictwo Zysk i S-ka.

25. Serafin, K. (2015). Kultura organizacyjna jako element wspierający realizację strategii przedsiębiorstwa. Studia Ekonomiczne. Zeszyty Naukowe Uniwersytetu Ekonomicznego w Katowicach, $n r 322$.

26. Sikorski, C. (2008). O zaletach słabej kultury organizacyjnej. Zarzadzanie Zasobami Ludzkimi, $n$ r 6.

27. Stańda, A. (2012). Dorobek strategicznej kultury organizacyjnej. In: A. Sopińska (eds.), Wspótczesne przedsiębiorstwa. Teoria i praktyka. Warszawa: Oficyna Wydawnicza SGH.

28. Steinmann, H., Schereyögg, G. (1995). Zarządzanie. Podstawy kierowania przedsiębiorstwem. Koncepcje, funkcje, przykłady. Wrocław: Oficyna Wydawnicza Politechniki Wrocławskiej.

29. Stoner, J.A.F., Wankel, Ch. (1994). Kierowanie. Warszawa: PWE.

30. Sułkowski, Ł. (2008). Czy warto zajmować się kulturą organizacyjną? Zarządzanie Zasobami Ludzkimi, nr 6.

31. Szaban, J. (2007). Wstęp - Raport z badań pogłębionych - analiza przypadków. In: H. Król (eds.), Zarzadzanie kapitałem ludzkim a konkurencyjność matych $i$ średnich przedsiębiorstw. Warszawa: Wydawnictwa Akademickie i Profesjonalne.

32. Zbiegień-Maciąg, L. (2013). Kultura $w$ organizacji. Identyfikacja kultur znanych firm. Warszawa: PWN. 